\title{
The Climate Community of Practice in the Gulf of Mexico: A Method for Multi-Disciplinary Climate Education and Outreach Support
}

\author{
MELISSA DAIGLE ${ }^{1 *}$, TRACIE T. SEMPIER ${ }^{2}$ \\ Volume 3, Spring 2015 \\ http://dx.doi.org/10.3998/mjs.12333712.0003.007 \\ 'Louisiana Sea Grant, 205 Sea Grant Building, Baton Rouge, LA 70803 \\ ${ }^{2}$ Mississippi-Alabama Sea Grant, 703 East Beach Drive, Ocean Springs, MS 39564 \\ ${ }^{*}$ Corresponding Author: Melissa Daigle, mtrosc2@tigers.Isu.edu
}

\section{ABSTRACT}

The Climate Community of Practice in the Gulf of Mexico (CoP) was formed in 2010 by the four Gulf Sea Grant Offices (Texas Sea Grant, Louisiana Sea Grant, Florida Sea Grant, and the Mississippi-Alabama Sea Grant Consortium). The goal of the CoP is to connect professionals who aim to achieve common outcomes and who, by working together, seek to develop a set of effective common approaches to climate change adaptation that can be refined over time. The CoP is composed of more than 300 members across 132 organizations, businesses, and local governments. Members have backgrounds that cover every aspect of climate-related issues, including the natural sciences, social sciences, outreach, education, law and policy. The core of the CoP is a workshop, held yearly since 2010 . The workshop rotates among the five Gulf states and provides members with information on the latest climate science, demonstrations of new tools for the visualization of sea-level rise, updates on policies that could be impacted by sea-level rise, and best practices from local governments. Throughout the year, the CoP hosts webinars on topics suggested by members and keeps in touch through an online networking site called StormSmart Coasts. In addition, the CoP awards small grants to local communities to address climate-related vulnerabilities. This article will examine lessons learned, 
as well as the elements that make the $\mathrm{CoP}$ an effective way to increase climate change outreach and awareness through workshops, webinars, trainings, research projects, and community small grants.

\section{The Need}

A recent climate perceptions survey sponsored by the Climate Community of Practice in the Gulf of Mexico (CoP) revealed that Gulf Coast communities perceive very different changes in their local environments, which condition their attitudes toward local government response (Goidel 2013). Therefore, developing a strong support network to share common experiences is vital in this region. CoPs provide a context in which people can communicate in order to build insight and understanding. They help participants to capture and diffuse existing knowledge and improve practice. Together, CoP members can define a process for tackling challenges, identify solutions to common problems, evaluate various approaches, and determine best practices (Cambridge, Kaplan, and Suter 2005). The Gulf of Mexico CoP allows participants to organize around purposeful actions, which eventually leads to tangible results. For example, CoP members identified the importance of delivering common messages when communicating about climate stressors and worked together to produce a rack card on the " 5 Things You Need To Know About Sea Level Rise" for dissemination to local stakeholders. The Gulf Climate CoP, like others studied, "capitalize[s] on shared experiences and contributions to develop the best possible educational products and then constantly strive[s] to improve those products based upon customer needs and feedback" (Sobrero and Craycraft 2008). This is especially important for the local government stakeholders served by the CoP because it ensures an iterative creation of products and tools that involves input and feedback at all stages of development. Recently, members of the CoP reviewed the utility of NOAA's Sea Level Rise viewer and gave input on additional layers and data they would need in order to make it more locally applicable. Additionally, when Louisiana sea-level rise data became available in the viewer, CoP members responded to the data and voiced concerns over its accuracy; based on this input, NOAA decided to delay the public release until the data could be refined. 


\section{Successes and Lessons Learned}

As the CoP celebrates its fifth year, we have learned a number of lessons regarding this model for sharing information among practitioners and the local communities they serve. First, involving local municipalities as partners has proven beneficial to the education, outreach, and extension (EOE) specialists, as well as to local government representatives. At each CoP workshop, community representatives from each Gulf state are represented on a panel that focuses on how local governments are addressing climate change. The CoP encourages local municipalities to participate by waiving the registration fee; by providing travel assistance to cover all or a portion of flight, mileage, and hotel costs; by offering small grants as incentives; and by giving local governments a prominent place on the meeting agenda. Recipients of the first small grant awards were competitively selected, and they leveraged existing resources with the award funding (between $\$ 15,000-\$ 30,000$ per award) to address vulnerabilities to climate stressors (e.g., sea-level rise). The funding for these activities comes from a variety of sources and varies from year to year. Sometimes it is covered by the Gulf Sea Grant offices, at other times by federal agencies such as the National Oceanic and Atmospheric Administration (NOAA). These benefits motivate local government staff to attend by removing barriers such as the difficulty of justifying travel outside of their municipalities. Being a part of the CoP helps EOE specialists and local governments come together to implement projects that address issues related to climate change. For example, several EOE specialists in Louisiana teamed up with the LA-1 Coalition, a group organized to secure funding to elevate Louisiana Highway 1 . Together they presented an all-day workshop to local governments and levee boards in Lafourche Parish on how sea-level rise will impact levee and road infrastructure. The idea for the workshop emerged from a CoP workshop, and the results were presented at another workshop the following year. In a second example, an EOE specialist in Mississippi worked with the City of Biloxi, which received funding to communicate climate risks to residents and city officials. This project involved updating the city's hazard mitigation plan to include sea-level rise, revising the annual flood risk mailer to include an entire section on the impacts of climate change, conducting outreach at local events and gathering places (e.g., festivals and malls) about the increased flooding risks associated with sea-level rise, and amending portions of the city's flood damage and prevention ordinance to include one foot of additional freeboard above the base flood elevation.

Another best practice revealed over the past five years is to establish a common framework within which the CoP operates. With input from participants at the an- 


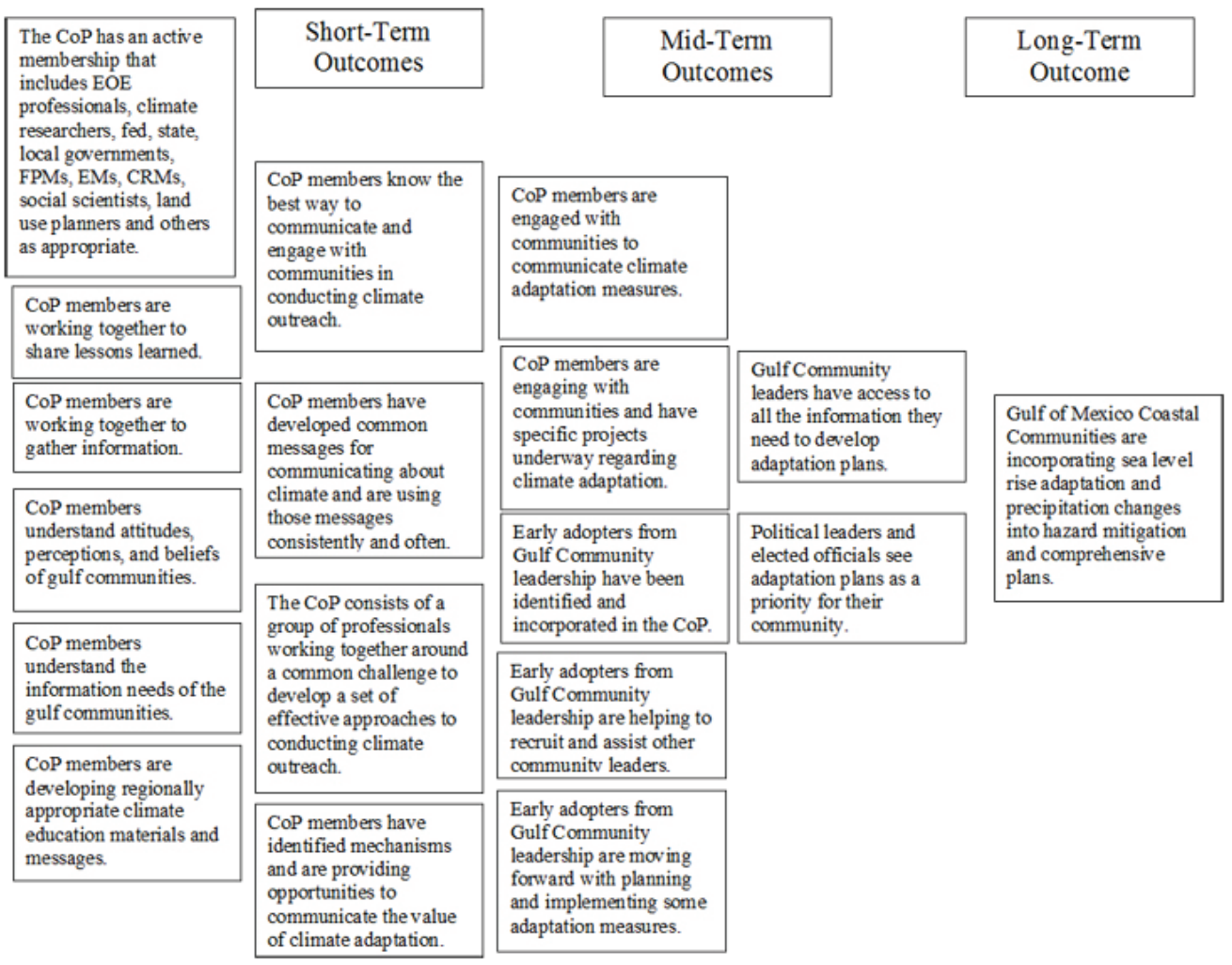

Figure 1. Climate community of practice logic model.

nual meetings, the Gulf of Mexico CoP developed a logic model with short-, mid-, and long-term goals. A logic model visually displays goals, resources, activities, and outputs. It serves as a roadmap for what the group hopes to accomplish and establishes a shared mission. Revisiting the logic model periodically allows CoP members to evaluate what the group has accomplished and what it hopes to achieve in the future.

The CoP has also created several work groups that allow members who have the time and interest to assist with its basic functions. Two of the most successful include the meeting-planning work group and the webinar work group. The meetingplanning group helps to create the agenda for yearly meetings and secure guest speakers. The CoP has worked closely with NOAA's Office for Coastal Management (OCM) on meeting planning. Since the CoP's inception, three staff members of OCM have provided meeting organization and facilitation services. Similarly, the 
webinar work group arranges topics and speakers for webinars held throughout the year. The CoP also has several topic-specific work groups, including ones for messaging, awards, evaluation, and formal/informal educational engagement.

Finally, the CoP has revealed the advantages of having an established regional network on a single topic. In recent years, funding opportunities and climate assessment information have been passed to many regional stakeholders through CoP members. With the wealth of information available, having a network that already communicates regularly on these topics makes it easier to stay up to date on the latest climate science, share best practices, and identify needs across the region. Responding to questions posed by the President's Task Force on Climate Change with a unified voice and delivering a common message when approaching stakeholders are just two ways the larger network expands the efforts of individual actors.

\section{Challenges to Overcome}

There are a number of challenges to maintaining and sustaining a CoP across such a broad and diverse region. For example, as meetings move from state to state, there is no centralized location for maintaining the organization's finances or housing the member contact information, other than a listserv that is passed from member to member. When participation is voluntary, it is also difficult to keep members engaged in the midst of the distractions of their daily jobs. Work groups are only as strong as the time and commitment of the chairs leading them, and the membership and activity of the various work groups tend to wax and wane as a result. Furthermore, no single person is dedicated to coordinating the overall membership, which makes it challenging to maintain momentum and to preserve historical knowledge of the group. Finally, the science of climate change changes rapidly, so the meeting and webinar work groups must stay up to date on the latest issues and concerns to make sure that the workshops and webinars are delivering relevant, scientifically sound information.

Overall, members indicate that the CoP has been a valuable resource, from providing the latest information on climate issues to offering networking opportunities that can lead to regional partnerships. It has also led to the development of other climate-related Communities of Practice, including those for the Southeast/Caribbean and the Great Lakes. According to Wenger, McDermott, and Snyder (2002), communities of practice often move through several developmental phases: potential (discovering common ground), coalescing (finding value in engaging), matur- 
ing (defining a learning agenda), stewardship (sustaining energy and renewing interest), and legacy (moving on and keeping in touch). The Gulf of Mexico Climate $\mathrm{CoP}$ is still maturing, concentrating on attracting new members and taking on new projects. Moving forward, it will be essential for CoP leadership to maintain momentum and a clear direction, which will require continual refining of the group's logic model. The CoP must also provide its members with opportunities to take on new roles and experiment with new activities. Determining a return on investment for sponsors of the $\mathrm{CoP}$ is a goal for the coming year. Finally, evaluating member needs will also be key for a healthy future.

\section{References}

Cambridge, D., Soren Kaplan, and Vicki Suter. 2005. "Community of Practice Design Guide: A Step-by-Step Guide for Designing and Cultivating Communities of Practice in Higher Education.” Accessed November 3, 2014. http://net.educause.edu/ir/library/pdf/nli0531.pdf.

Goidel, Kirby. 2013. "Local Climate Shifts and Public Opinion toward Climate Change in the Gulf Coast." Paper presented at the conference of the Southern Political Science Association, Orlando, FL, January.

Sobrero, Patricia M., and Carla Gale Craycraft. 2008. "Virtual Communities of Practice: A $21^{\text {st }}$ Century Method of Learning, Programing, and Developing Professionally." Journal of Extension 45 (5). Accessed October 24, 2014. http://www.joe.org/joe/2008october/a1.php.

Wenger, Etienne, Richard McDermott, and William Snyder. 2002. Cultivating Communities of Practice: A Guide to Managing Knowledge. Boston: Harvard Business School Press. 